\title{
Acute Hepatitis Associated with Thymus Vulgaris Oil Ingestion; Case Report
}

\author{
Kekik Yağı Alımına Bağlı Akut Hepatit; Olgu Sunumu
}

\author{
Aslıhan YÜRÜKTÜMEN, ${ }^{1}$ Nil HOCAOĞLU, ${ }^{2}$ Murat ERSEL, ${ }^{3}$ Murat ÖZSARAÇ, ${ }^{3}$ Selahattin KIYAN ${ }^{3}$ \\ 'Department of Emergency Medicine, Akdeniz University Faculty of Medicine, Antalya; \\ ${ }^{2}$ Department of Pharmacology, Dokuz Eylul University Faculty of Medicine, Izmir; \\ ${ }^{3}$ Department of Emergency Medicine, Ege University Faculty of Medicine, Izmir, all in Turkey
}

\begin{abstract}
SUMMARY
Many plants traditionally used in folkloric medicine can cause poisoning. Typically known as "thyme", "Thymus Vulgaris" continues to be one of the most commonly used folkloric herbs in Turkey. Here, we report a case of toxic hepatitis due to the ingestion of concentrated thyme oil. The patient was reported to have ingested a total of $25 \mathrm{ml}$ of thyme oil which was routinely sold in the local market. The total dose was taken in two consecutive days in different amount. The patient then developed nausea, vomiting and diarrhea, and he was subsequently admitted to the emergency unit, with high transaminase levels. He was placed on observation unit for two days. His elevated aminotransferase levels and symptoms gradually decreased during the observation period. Thyme, which is known to be a nonpoisonous plant, is one of the most commonly used herbs; however, plants similar to thyme are not necessarily as harmless as they seem to be.
\end{abstract}

Key words: Hepatitis; poisoning; thyme.

\section{ÖZET}

Folklorik tıpta geleneksel olarak kullanılan pek çok bitkisel ürün zehirlenmeye neden olabilmektedir. Ingilizce yaygın ismi "Thyme" olan Thymus Vulgaris (Kekik) Türkiye'de sıklıkla kullanılan bitkisel ürünlerden biridir. Bu olguda konsantre kekik yağı alımı ile ortaya çıkmış bir toksik hepatit vakası bildirmekteyiz. Marketlerde ticari bir ürün olarak satılan toplam 25 ml'lik kekik yağını içen hastamız bulantı, kusma ve ishal gelişen hasta yüksek transaminaz düzeyleri ile acil serviste izlendi. İi gün gözlemde kalan hastanın semptomları ve aminotransferaz yüksekliği tedricen azaldı. Çok sık kullanılan bitkisel ürünlerden biri olan ve zehirli olmadığı bilinen kekik benzeri bitkilerin de göründüğu kadar zararsız olmayabileceği bilinmelidir.

Anahtar sözcükler: Hepatit; zehirlenme; kekik.

\section{Introduction}

The widespread use of medicinal herbs among the general population gives rise to the possibility of toxic and adverse effects in patients that use these plants. Thymus Vulgaris (thyme) has generally been thought of as a nontoxic herb and it's one of the most commonly used herbs in Turkey and
Europe $^{[1-4]}$ In Turkey, thyme was traditionally used to treat medical symptoms such as coughing, upper respiratory congestion, gastritis, bronchitis, spasm, sprains, stomach cramps, dysmenorrhea, dyspepsia, and urinary tract infection. It contains essential oils, such as phenols thymol and carvacrol, glycosides, flavonoids, p-cymene, borneol,

Submitted (Geliş tarihi): December 10, 2010 Accepted (Kabul tarihi): January 31, 2011

Correspondence (IIletişim): Aslıhan Yürüktümen, M.D. Akdeniz Üniversitesi Tıp Fakültesi, Acil Tıp Anabilim Dalı, Antalya, Turkey

e-mail (e-posta): ayuruktumen@gmail.com 
linalool, eugenol, alcohols, rosmarinic acid, saponins, tannins and terpenoid. ${ }^{[1,5-7]}$ The American Association of Poison Control Centers (AAPCC) reported 8.466 telephone enquiries including 6.879 children and 967 adults, who were thought to have been poisoned with essential oils $(0.32 \%$ of all poisonings) in 2007. Of the essential oil exposures, 7.790 (92.01\%) were unintentional and 168 (1.98\%) were intentional. Clinical effects were shown as mild for 1.512 (17.85\%), moderate for 119 (1.41\%) and major for $3(0.04 \%)$ cases reported to the AAPCC and $21.66 \%$ of them had no symptoms of toxicity. ${ }^{[8]}$ In another study, essential oils accounted for $0.69 \%$ of poisonings (185 cases) in Israel. ${ }^{[9]}$

There are several case reports on the use of Thyme oil or extracts toxicity presented with nausea, vomiting, tachypnea, hypotension, hypersensitivity; however, toxic hepatitis had not been reported in the literature..$^{[1,10-12]}$

We report a case of toxic hepatitis which resulted from a patient intentionally ingesting large amounts of Thyme oil.

\section{Case Report}

A 38-year-old male patient was referred by a general practitioner to Ege University Hospital Department of Emergency Medicine, Izmir (Turkey) with the diagnosis of acute toxic hepatitis. The patient stated he received a total of $25 \mathrm{ml}$ of a commercial and original product of thyme oil for his dyspeptic complaints including indigestion and heatburn for two days. The dose of thyme oil, which was not recommended by a healthcare provider and was used for the first time by the patient, was confirmed to be above the recommended dose for the particular product. He then developed nausea, vomiting, diarrhea and was therefore admitted to a state hospital where he stayed for 8 hours for various diagnostic tests and initial treatment to be completed. When high levels of aminotranferase were detected in the patient, he was referred to our emergency department, with the diagnosis of a toxic hepatitis. His medical history was not remarkable except for the splenectomy due to blunt abdominal trauma he had experienced 10 years ago. He denied ingesting any other herbs, drugs and ethanol (acute or chronic).

Vital signs on presentation to our facility were as follows: blood pressure $120 / 70 \mathrm{mmHg}$, pulse 86 / beats per minute, respiratory rate 12 / breaths per minute, temperature $36.2^{\circ} \mathrm{C}$, oxygen saturation $98 \%$ on room air. Physical examination including mental status, skin, sclera, abdominal and neurologic examination was normal. Tonic-clonic generalize convulsion, flapping tremor and hepatic encephalopathy were not detected. Laboratory studies revealed aspartate transaminase $1470 \mathrm{U} / \mathrm{L}$ (range $<35 \mathrm{U} / \mathrm{L}$ ), alanine transaminase $506 \mathrm{U} / \mathrm{L}$ (range < $45 \mathrm{U} / \mathrm{L}$ ), total bilirubine $1.02 \mathrm{mg} / \mathrm{dL}(0.1-1$ $\mathrm{mg} / \mathrm{dL}$ ), prothrombin time 17.2 seconds (10.9-14.7 seconds), International Normalized Ratio 1.38 (range 0.9-1.2), urea 31 $\mathrm{mg} / \mathrm{dl}(10-50 \mathrm{mg} / \mathrm{dl})$ and creatinine $0.77 \mathrm{mg} / \mathrm{dl}(0.7-1.3 \mathrm{mg} /$ $\mathrm{dl}$ ) in the emergency department. The rest of the laboratory test results, including complete blood count, alkaline phosphatase and electrolytes, were within normal limits.

Abdominal ultrasound showed normal hepatobiliary structure. Viral serology including Hepatitis C Virus (HCV) Antibodies, Hepatitis B Surface (HBs) Antigen, Hepatitis B Surface (HBs) Antibodies, Hepatitis A Virus (HAV) Ig M and Ig G Antibodies, Hepatitis B Core ( $\mathrm{HBC}$ ) Ig M Antibodies, Ig $M$ Antibodies against Epstein-Barr Virus Viral Capsid Antigen (EBV-VCA), Cytomegalovirus (CMV) Ig M Antibodies were negative, Hepatitis B e (HBe) Antibody, Cytomegalovirus (CMV) Ig G Antibodies and Ig G Antibodies against EpsteinBarr Virus Viral Capsid Antigen (EBV-VCA) were positive. Echocardiography revealed normal ejection fraction on both ventricles. The content of substance could not be evaluated in the laboratory because the product was completely digested. The blood level of drug or substance was not measured, because additional herb (or drug) intake did not exist in the patient history. He was admitted with the initial diagnosis of toxic hepatitis due to thyme oil.

$\mathrm{N}$-acetylcysteine $300 \mathrm{mg}$ per hour $(150 \mathrm{mg} / \mathrm{kg}$, during 50 hours) for toxic hepatitis (for cases similar to essential oil or acetaminophen poisoning) and metoclopramide (10 mg) for recurrent vomiting were administered intravenously on the first and second days of patient observation. ${ }^{[13]}$ During the observation period, his elevated aminotransferase levels (Table 1) and symptoms gradually decreased. No complications associated with hepatotoxicity were observed on his survey associated with hepatotoxicity and he was discharged with full recovery on the 9th day of his admission.

\section{Discussion}

Thyme is an herbaceous perennial plant belonging to the Lamiaceae family. The key constituents of thyme include essential oils; such as the phenols thymol and carvacrol, glycosides, flavonoids, p-cymene, borneol, linalool, eugenol, alcohols, rosmarinic acid, saponins, tannins and terpenoid. [1,5-7] Thymol and carvacrol have been reported to act as antioxidants, antimicrobial agents, antifungal agents, diuretic, urinary disinfectants, and they have been used in the treatment of respiratory tract diseases, healing wounds, treating gas in the digestive system, and regarded as substances that expel worms from bodies; in other words as antihelmintic. ${ }^{[1,14,15]}$ Thyme is generally recognized as having a safe (GRAS) status when it is used in moderate amounts in foods. ${ }^{[1,16]}$ When thyme oil is used either orally 
Table 1. Laboratory exam

\begin{tabular}{lccccc}
\hline Hours & $\begin{array}{c}\text { AST } \\
\mathbf{( U / L )}\end{array}$ & $\begin{array}{c}\text { ALT } \\
\mathbf{( U / L )}\end{array}$ & $\begin{array}{c}\text { T. Bilirubin / D. Bilirubin } \\
\mathbf{( m g / d I )}\end{array}$ & $\begin{array}{c}\text { PTz (second) / INR } \\
\text { (U/L) }\end{array}$ & GGT \\
24 hours & 1470 & 506 & $1.02 / 0.6$ & $17.2 / 1.38$ & - \\
38 hours & 5558 & 1581 & $1 / 0.61$ & $15.9 / 1.27$ & 419 \\
54 hours & 3284 & 1529 & $1.38 / 0.74$ & $14.4 / 1.15$ & 564 \\
69 hours & 1289 & 1026 & $1.01 / 0.62$ & $12.7 / 1$ & 554 \\
9th day & 15 & 14 & $0.9 / 0.2$ & - & 11 \\
* Normal value; AST (Aspartate Transaminase)<35 U/L, ALT (Alanine Transaminase) <45 U/L, Total bilurubin 0.1-1.0 mg/dl, direct bilurubin \\
0-0.25 mg/dl, INR 0.9-1.2, PTz (Prothrombin time) 10.9-14.7 second, GGT (Gamma-glutamyl transferase) <55 U/L.
\end{tabular}

or topically in a non-diluted form, it may be recognized as unsafe. However, there is limited scientific evidence supporting any optimal dose of thyme oil. It is considered to be highly toxic, and moreover, safety and efficacy have not been proven. ${ }^{[1,11,13,17]}$ Two to three drops of thyme oil on a sugar cube 2 to 3 times on a daily basis were experimented. ${ }^{[1,12]}$ Essential signs of toxicity included hypersensitivity reaction, nausea, vomiting, tachypnea and hypotension. ${ }^{[1,11,12]}$ Dietary administration of $2 \%$ thyme extract caused slightly but significantly higher xenobiotic-metabolizing enzymes such as 7-ethoxycoumarin Odeethylase (ECOD), glutathione S-transferase (GST), and quinone reductase (QR) activities in another study. ${ }^{[17]}$ On the other hand, Eugenol which is a component of thyme oil from Thymus capitatus, cilicus, funkii, and vulgaris, is hepatotoxic. ${ }^{[6,7,13]}$ For instance, in children, as little as $10 \mathrm{ml}$ of eugenol-containing clove oil has led to near fatal hepatic failure. ${ }^{[18]}$

Our study had some limitations. The blood level of drug or substance could not be measured (by analysis of toxicological screen and essential oils with chromatography method) because additional herb (or drug) intake did not exist in the patient history and rapid recovery of symptoms after stopping thyme oil intake was stated by the patient.

This case involved toxic hepatitis after ingestion of large amounts of Thyme oil. There are several studies that exist on the toxic effects of thyme; however there is no other similar case found to be reported in the literature. ${ }^{[1,11,17,18]}$ In our case, the patient received large amounts of thyme oil $(25 \mathrm{cc}$ ) relative to daily practice (2-3 drops a day). Other causes of acute hepatitis were eliminated in the emergency department. Normal ejection fraction and serologic markers excluded cardiac failure and acute hepatropic viral infection, which may cause transaminase elevation respectively. The patient denied ingestion of any concomitant drugs or herbs. His level of transaminase decreased within 10 days after cessation of thyme oil intake. Supportive treatment with intravenous n-acetyl sistein might have contributed in his improvement.

\section{Conclusions}

Thyme, which is known to be a nonpoisonous plant, is one of the most commonly used herbs. However, it should be kept in mind that plants similar to thyme, which are used in traditional medicine, may not necessarily be as harmless as they are expected to be. In our case, toxic hepatitis developed following ingestion of large amounts of thyme oil.

\section{References}

1. Basch E, Ulbricht C, Hammerness P, Bevins A, Sollars D. Thyme (Thymus vulgaris L.), thymol. J Herb Pharmacother 2004;4:4967.

2. Bardia A, Nisly NL, Zimmerman MB, Gryzlak BM, Wallace RB. Use of herbs among adults based on evidence-based indications: findings from the National Health Interview Survey. Mayo Clin Proc 2007;82:561-6.

3. Verhoef MJ, Sutherland LR, Brkich L. Use of alternative medicine by patients attending a gastroenterology clinic. CMAJ 1990;142:121-5.

4. Devesa Jordà F, Pellicer Bataller J, Ferrando Ginestar J, Borghol Hariri A, Bustamante Balén $M$, Ortuño Cortés J, et al. Consumption of medicinal herbs in patients attending a gastroenterology outpatient clinic. Gastroenterol Hepatol 2004;27:244-9. [Abstract]

5. Atti-Santos AC, Pansera MR, Paroul N, et al. Seasonal variation of essential oil yield and composition of Thymus Vulgaris $L$. (Lamiaceae) from South Brazil. JEOR 2004;16:294-5.

6. GRIN Taxonomy Plants, United States Department of Agriculture, Germplasm Resources Information Network Web Site. Available at: http://www.ars-grin.gov/cgi-bin/npgs/html/ taxon.pl?36631. (Accessed January 20, 2011).

7. Ozcan M, Chalchat J. Aroma profile of Thymus Vulgaris L. Growing wild in Turkey. Bulg J Plant Physiol 2004;30:68-73.

8. Bronstein AC, Spyker DA, Cantilena LR Jr, Green JL, Rumack $\mathrm{BH}$, Heard SE; American Association of Poison Control Centers. 2007 Annual Report of the American Association of Poison Control Centers' National Poison Data System (NPDS): 25th Annual Report. Clin Toxicol (Phila) 2008;46:927-1057.

9. Bentur Y, Lurie Y, Cahana A, Lavon O, Bloom-Krasik A, Kovler $\mathrm{N}$, et al. Poisoning in Israel: annual report of the Israel Poison 
Information Center, 2007. Isr Med Assoc J 2008;10:749-56.

10. Soo Hoo GW, Hinds RL, Dinovo E, Renner SW. Fatal largevolume mouthwash ingestion in an adult: a review and the possible role of phenolic compound toxicity. J Intensive Care Med 2003;18:150-5.

11. Harrison P, Bartels M. A modern appraisal of ancient Etruscan herbal practices. Am J Pharmacol Toxicol 2006;1:21-4.

12. Committee on Herbal Medicinal Products (HMPC), Community Herbal Monograph on Thymus Vulgaris L. and Thymus Zygis L. HERBA 2007. Available at: http://www.ema.europa. eu/docs/en_GB/document_library/Herbal_-_Community_ herbal_monograph/2009/12/WC500018081.pdf. (Accessed August 22, 2009).

13. Janes SE, Price CS, Thomas D. Essential oil poisoning: N-acetylcysteine for eugenol-induced hepatic failure and analysis of a national database. Eur J Pediatr 2005;164:520-2.

14. Kulisic T, Radonic A, Milos M. Antioxidant properties of thyme (Thymus Vulgaris L.) and wild thyme. Italian J Food Sci
$2005 ; 17: 315-24$.

15. Gruenwald J, Graubaum HJ, Busch R. Efficacy and tolerability of a fixed combination of thyme and primrose root in patients with acute bronchitis. A double-blind, randomized, placebocontrolled clinical trial. Arzneimittelforschung 2005;55:66976.

16. U.S. Government Printing Office, e-CFR Data, Food and Drugs, Substances Generally Recognized as Safe (GRAS). Available at: http://ecfr.gpoaccess.gov/cgi/t/text/text-idx?c=ecfr\&sid= 786bafc6f6343634fbf79fcdca7061e1\&rgn=div5\&view=text\& node $=21: 3.0 .1 .1 .13 \& i d n o=21$ (Accessed 22 August 2009).

17. Sasaki K, Wada K, Tanaka Y, Yoshimura T, Matuoka K, Anno T. Thyme (Thymus vulgaris L.) leaves and its constituents increase the activities of xenobiotic-metabolizing enzymes in mouse liver. J Med Food 2005;8:184-9.

18. Hartnoll G, Moore D, Douek D. Near fatal ingestion of oil of cloves. Arch Dis Child 1993;69:392-3. 